\title{
The Struggle Is Real: Constraints of Online Education in Indonesia During the COVID-19 Pandemic
}

\author{
Mahir Pradana * and Syarifuddin Syarifuddin \\ Department of Business Administration, Telkom University, Bandung, Indonesia
}

Keywords: education, COVID-19, Indonesia, policy, school

\section{INTRODUCTION}

The COVID-19 pandemic has forced millions of Indonesian children to shift their educational situation from offline to online (Wiguna et al., 2020). Around 60 million primary to upper secondary school students and eight million vocational school students have to study at home and rely on online technology since the government decided that schools are indefinitely closed (JPNN, 2020). However, social problems raised since a significant percentage of school students do not have access to online teaching and learning facilities (Wahyono et al., 2020).

Ministry of Education and Culture of Indonesia has prepared for the scenario to study online until

OPEN ACCESS

Edited by:

Mert Bastas,

Near East University, Cyprus

Reviewed by:

Ngakan Putu Anom Harjana, Mahidol University, Thailand

Gülyüz Debes,

University of Mediterranean Karpasia,

Cyprus

*Correspondence:

Mahir Pradana

mahirpradana@

telkomuniversity.ac.id

Specialty section:

This article was submitted to Educational Psychology,

a section of the journal

Frontiers in Education

Received: 16 August 2021

Accepted: 30 August 2021

Published: 13 September 2021

Citation:

Pradana M and Syarifuddin S (2021) The Struggle Is Real: Constraints of Online Education in Indonesia During the COVID-19 Pandemic.

Front. Educ. 6:753776.

doi: 10.3389/feduc.2021.753776 the end of 2020 (Pradana et al., 2020). However, the infection number keeps rising, and per December 2020, Indonesia is now among the top 20 countries with the highest numbers of cases (around 650,000 cases). Hence, there is a high probability that schools are closed until mid-2021.

There is already some talks of government plans to reopen schools and start face-to-face learning in 2021. Parents are given the option to choose whether they want their children to participate in this face-to-face learning activity. In its implementation, local governments, schools, and parents will be given full authority. However, health researchers, such as epidemiologists, argue that this decision is counter-productive in limiting the coronavirus's spread (Viner et al., 2020).

The positivity rate is the first reason why it is still unsafe to reopen schools in Indonesia. It is relatively safe to reopen schools when the positivity rate is at least 5 percent or below (WHO, 2020). However, Indonesia's positivity rate test is still above 10 percent until December 2020, which shows the severity of COVID-19 pandemic in this country (Wiguna et al., 2020).

\section{STRUGGLES OF STUDENTS AND THEIR PARENTS}

On the other hand, there is a necessity to organize classroom learning for students who have difficulty accessing digital learning facilities during the Coronavirus pandemic. A significant number of Indonesian students face the problems of not having cell phones or being unable to buy internet data plan to access the internet. The effectiveness of online education at home during the COVID-19 pandemic period has been monitored by the Indonesian Child Protection Commission (KPAI). According to a survey conducted by the commission in 34 provinces of Indonesia, online learning constraints are becoming a serious consideration (Satryo, 2020).

The Coronavirus pandemic has put heavy pressure on groups of society who live under poverty. When teaching and learning activities cannot be face-to-face, children from low-income families do not have the facilities to access digital learning. Indigent parents have difficulties in affording cellular credits, let alone buying internet data plans. Since the middle of 2020 , the ministry of education distributed subsidies in the form of internet data plans. However, it was not a sufficient answer to the problems of online education (Fakhri et al., 2020). 
We also conducted short social survey on 1,700 school students and their parents as respondents. The survey focused on several constraints in carrying out online learning process during the coronavirus pandemic. We distributed the questionnaire in Indonesian main islands, which are also the most populated (Java, Sumatra, Kalimantan, Sulawesi, and Papua). However, due to limited time and budget, we only managed to distribute the survey online. To make sure that respondents from each island represent the population, we distributed the survey proportionally from the most populated island (Java) to the least populated one (Papua).

The result showed that most students or the students' parents complain about the internet data plan subsidy, which is not evenly distributed to Indonesia's rural areas. There was 43 percent of total respondents complaining about that constraint. Other 29 percent of the respondents explained that the subsidy was of no use for them since they do not have computers, laptops, nor smartphones. This group of parents rely on laptops or smartphones that they borrow from families or relatives. The rest, around $18 \%$, are those who do not have everything. We should also consider that around $70 \%$ of the respondents complain that they keep having internet connection problems.

\section{STRUGGLES OF THE SCHOOL TEACHERS}

The previous section recognizes the main problem that online education cannot be equally applied in all parts of Indonesia. For dealing with these issues, several teachers have been taking the

\section{REFERENCES}

Fakhri, M., Pradana, M., Syarifuddin, S., and Suhendra, Y. (2020). Leadership Style and its Impact on Employee Performance at Indonesian National Electricity Company. Open Psychol. J. 13 (1), 321-325. doi:10.2174/ 1874350102013010321

JPNN (2020). Belajar Jarak Jauh, Tetapi Guru Terpaksa Datangi Rumah-Rumah Siswa (Distance Learning, but Teachers Are Forced to Go to Students' Homes). Available at: https://www.jpnn.com/news/belajar-jarak-jauh-tetapi-guruterpaksa-datangi-rumah-rumah-siswa?page=2 Accessed: January 3, 2021.

Pradana, M., Rubiyanti, N., S., W., Hasbi, I., and Utami, D. G. (2020). Indonesia's Fight Against COVID-19: The Roles of Local Government Units and Community Organisations. Local Environ. 25 (9), 741-743. doi:10.1080/ 13549839.2020.1811960

Satryo, A. (2020). Survei KPAI Tentang Efektifitas Belajar Daring: 43 Persen Tidak Memiliki Kuota, 29 Persen Tidak Punya HP (KPAI Survey on Online Learning Effectiveness: 43 Percent Don't Have Quota, 29 Percent Don't Have Cellphones). RMOL. Available at: https://nusantara.rmol.id/read/2020/08/08/ 447142/survei-kpai-tentang-efektifitas-belajar-daring-43-persen-tidak-memilikikuota-29-persen-tidak-punya-hp.

Taufiqurrahman, T. (2020). Kisah Viral Guru Avan, Datangi Satu Per Satu Rumah Murid untuk Mengajar di Tengah Pandemi Corona (The Viral Story of Teacher Avan, Going to Students' Houses to Teach in the Middle of the Corona Pandemic). Kompas. Available at: https://regional.kompas.com/read/2020/ 04/18/14595211/kisal-viral-guru-avan-datangi-satu-per-satu-rumah-muriduntuk-mengajar-di?page=all Accessed: January 27, 2021.

Viner, R. M., Russell, S. J., Croker, H., Packer, J., Ward, J., Stansfield, C., et al. (2020). School Closure and Management Practices During Coronavirus Outbreaks Including COVID-19: A Rapid Systematic Review. Lancet Child. Adolesc. Health 4, 397-404. doi:10.1016/S2352-4642(20)30095-X initiatives to come to their students' homes and carry the learning process in groups with a maximum of five students (Taufiqurrahman, 2020). These teachers agreed that online learning online at their places did not go smoothly. The reason they often faced is that many students do not have smartphones or other required gadgets. They also had difficulty controlling the activities of students since they did not have classroom interaction (Wahyono et al., 2020).

At the students' residences, the visiting teachers realized that there are many parents who do not have personal computers, laptops or smartphones. Those who do are facing difficulties in purchasing internet data packages and acquiring decent internet signals. Therefore, it has now become common that teachers, especially in underdeveloped villages, decided to visit their students' homes one by one and bring various kinds of books for the students to read and study (Wahyono et al., 2020).

All of the situations we depicted in this essay are bitter reality. It is obvious that we are still unable to predict the end of the pandemic, but education cannot be postponed. The Indonesian government should be more aware about the gap in social welfare of Indonesian society and focus on specific solutions on the mentioned constraints of online education.

\section{AUTHOR CONTRIBUTIONS}

MP and SS wrote the manuscript together and approved the submitted version.

Wahyono, P., Husamah, H., and Budi, A. S. (2020). Guru profesional di masa pandemi COVID-19: Review implementasi, tantangan, dan solusi pembelajaran daring. Jurnal pendidikan profesi guru 1 (1), 51-65. Available at: http://ejournal.umm.ac.id/index.php/jppg/article/view/12462 Accessed: February 1, 2021. doi:10.22219/jppg.vli1.12462

WHO (2020). Director-General's Opening Remarks at the Mission Briefing on COVID-19. World Health Organization. Available online at: https://www.who. $\mathrm{int} / \mathrm{dg} /$ speeches/detail/who-director-general-s-opening-remarks-at-the-missionbriefing-on-covid-19.

Wiguna, T., Anindyajati, G., Kaligis, F., Ismail, R. I., Minayati, K., Hanafi, E., et al. (2020). Brief Research Report on Adolescent Mental Well-Being and School Closures During the COVID-19 Pandemic in Indonesia. Front. Psychiatry 11, 598756. doi:10.3389/fpsyt.2020.598756

Conflict of Interest: The authors declare that the research was conducted in the absence of any commercial or financial relationships that could be construed as a potential conflict of interest.

Publisher's Note: All claims expressed in this article are solely those of the authors and do not necessarily represent those of their affiliated organizations, or those of the publisher, the editors and the reviewers. Any product that may be evaluated in this article, or claim that may be made by its manufacturer, is not guaranteed or endorsed by the publisher.

Copyright (c) 2021 Pradana and Syarifuddin. This is an open-access article distributed under the terms of the Creative Commons Attribution License (CC $B Y)$. The use, distribution or reproduction in other forums is permitted, provided the original author(s) and the copyright owner(s) are credited and that the original publication in this journal is cited, in accordance with accepted academic practice. No use, distribution or reproduction is permitted which does not comply with these terms. 